\title{
Current Scenario of Air Quality in and Around the Vicinity of Maruthamalai Hill Shrine, Coimbatore
}

\author{
M.Thamaraikannan ${ }^{1,2}$ Dr M. Balakrishnan ${ }^{2}$ Dr.S. Sureshkumar ${ }^{1 *}$ \\ ${ }^{1,1 *}$ Department of Animal Resource and Science, Dankook University Cheonan-si, \\ Chungnam 31116, Korea \\ ${ }^{2}$ Department of Environmental Science, PSG College of Arts and Science, Coimbatore
}

\begin{abstract}
Air is one the major source for all living organisms to sustain on the earth. Nowadays due to heavy traffic and industrial population most of the cities are affected by air pollution. In this research the Marudhamalai Hill Shrine was selected as the study area to monitor the air quality in its vicinity. Marudhamalai is located on the Western Ghats in Coimbatore district. It is famous for the Murugan temple located on it as people from Coimbatore and other parts of India visit every year. From the results it was clear that the forest surrounding the hill shrine not have medicinal plants but these plants help in to maintain the air quality parameters resulting in the quality to be within the prescribed limits.
\end{abstract}

Keywords:- Air Quality Monitoring, $\mathrm{PM}_{10}, \mathrm{SO}_{2}, \mathrm{NO}_{2}$, Marudhamalai

\section{INTRODUCTION}

Air is one of the fundamental endurance components of the human life. Air includes blend of gases which is utilized in breathing and a great deal of different exercises. The blend contains a gathering of gases of about steady fixations and a gathering with focuses that are variable in both reality. By volume, dry air contains $78.09 \%$ Nitrogen, 20.95\% Oxygen, $0.93 \%$ Argon, $0.039 \%$ Carbon di-oxide, and modest quantities of different gases. Air likewise contains a variable measure of water fume, on normal around $1 \%$. Air has a basic impact in human's life, that one can't live without it in any event, for a couple of moments. It is important to protect the air breathable.

Air contamination might be depicted as pollution of the climate by vaporous, fluid, or solid wastes or by items that can jeopardize human well being and government assistance of plants and creatures, assault materials, decrease perceivability or produce unwanted scents. Albeit a few poisons are discharged by normal sources like volcanoes, coniferous forest, and underground aquifers, the impact of this contamination is little when contrasted with that brought about by emanations from modern sources, force and warmth age, squander removal, and the activity of inner burning motors. Fuel ignition is the biggest supporter of air contamination discharges, brought about by man, with fixed and versatile sources similarly capable. The air contamination issue is experienced open air just as indoor.

\section{MATERIALS AND METHODS}

\section{Study Area}

Maruthamalai hills, part of the Southern Western Ghats in Coimbatore district of Tamil Nadu lies between $76^{\circ} 55^{\prime} \mathrm{E}$ and $11^{\circ} 0^{\prime}$ and $11^{\circ} 5^{\prime} \mathrm{N}$. The forest type of this region is classified as dry deciduous. Annual rainfall is around $450 \mathrm{~mm}$ and temperature varying between $17^{\circ} \mathrm{C}$ and $38^{\circ} \mathrm{C}$. The altitudinal range between 450 to $975 \mathrm{~m}$ above MSL. The soil is generally shallow with sandy loam texture and rocky substratum is available at slope areas(Paulsamy, 2011). Western Ghats older than Himalayas is one of the 34 Global Hot spots of Biodiversity flora, fauna, landscape and ethnicity (Sindhuja et al., 2012).

\section{Sampling Locations}

Ambient air survey was conducted at Marudhamalai Hills and its surrounding areas using Respirable Dust Sampler APM 460 BL. Locations and other details are given in Table 1 and Table 2

\begin{tabular}{|c|c|}
\hline 1. & Near Marudhamalai Temple (Up) \\
\hline 2. & Car Parking Marudhamalai Temple (Up) \\
\hline 3. & Marudhamalai Entrance (Down) \\
\hline 4. & Marudhamalai Mini Bus Stand (Down) \\
\hline
\end{tabular}

Table 1:- Air Monitoring Sampling Stations Located At Marudhamalai 


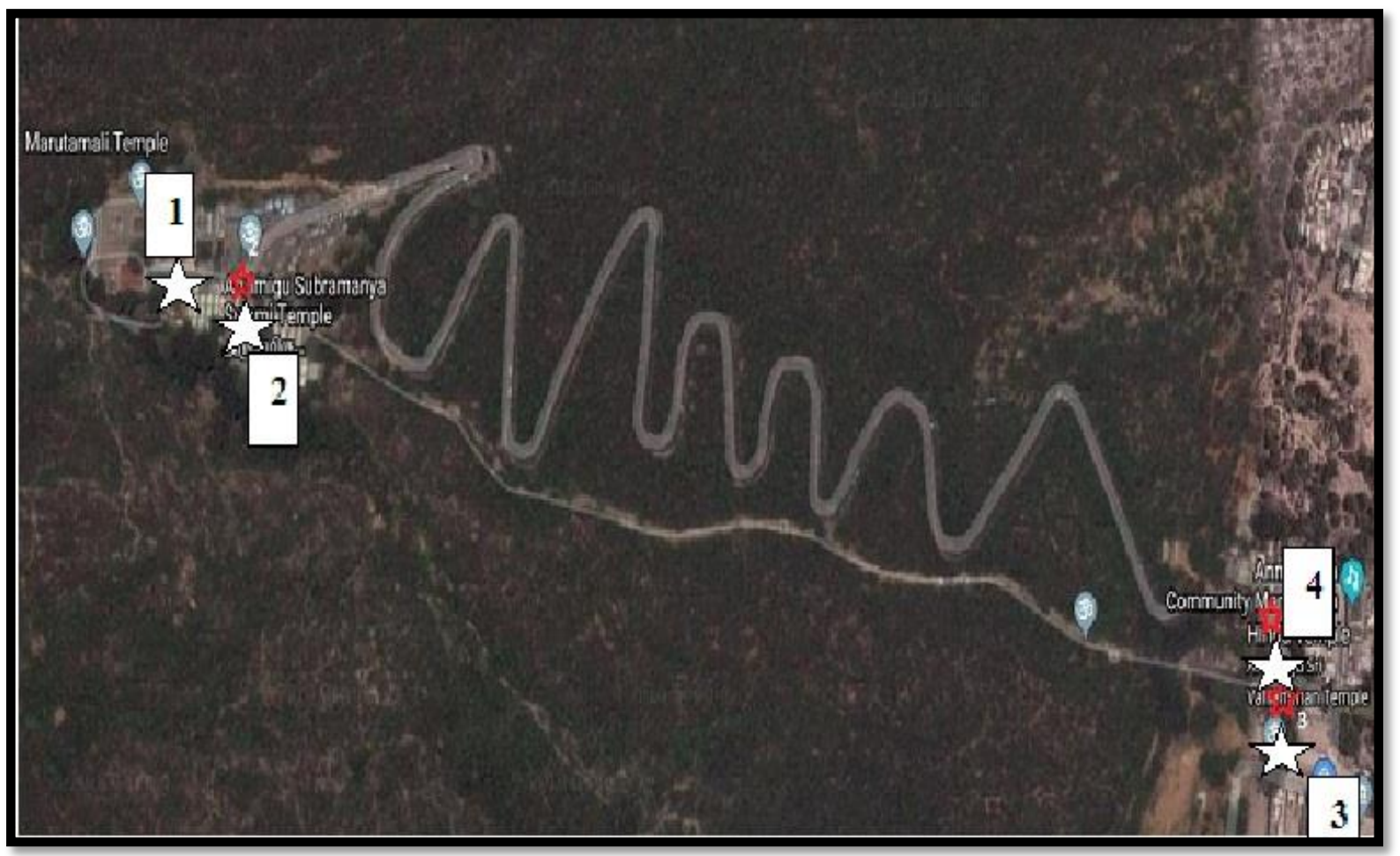

Fig 1:- Location of Air Sampling Sites

\section{$>$ Analysis}

Particulate Matter $\left(\mathrm{PM}_{10}\right)$, Sulphur dioxide $\left(\mathrm{SO}_{2}\right)$ and oxides of Nitrogen $\left(\mathrm{NO}_{2}\right)$ were measured using Respirable Dust Sampler, West and Gaeke method and Jacob Hochheiser method (Saravanakumar et al., 2016) respectively.

\section{RESULTS AND DISCUSSION}

\section{$>$ Air Quality}

According to Table 2 it was observed that the $\mathrm{PM}_{10}$, $\mathrm{SO}_{2}$ and $\mathrm{NO}_{2}$ concentrations obtained at the different locations are below the prescribed limit (Figure 2). The maximum and minimum $\mathrm{PM}_{10}$ was found to be in Marudhamalai Mini Bus Stand (Down) and Near Marudhamalai Temple (Up) respectively. Due to the presence of vehicular emissions from mini bus functioning at the hill shrine, the $\mathrm{PM}_{10}$ concentration showed maximum $\left(48.4 \mu \mathrm{g} / \mathrm{m}^{3}\right)$ than other four sites. According to Sharma and Gupta (2017) the 24 hour monthly average concentration of $\mathrm{PM}_{10}$ around the Golden temple was found $142 \mu \mathrm{g} / \mathrm{m}^{3}$. The maximum value for the $\mathrm{PM}_{10}$ concentration was $300 \mu \mathrm{g} / \mathrm{m}^{3}$ and was observed for the month of October. It is because of the fact that in this month along with stubble burning the crackers pollution during Diwali festival contributes towards air pollution. This value is about thrice the National Ambient Air Quality Standards (NAAQS, 2009) prescribed by the Central Pollution Control Board.
Similarly the maximum $\mathrm{SO}_{2}\left(15.6 \mu \mathrm{g} / \mathrm{m}^{3}\right)$ and $\mathrm{NO}_{2}$ $\left(30.4 \mu \mathrm{g} / \mathrm{m}^{3}\right)$ concentrations were also recorded at the Marudhamalai Mini Bus Stand (Down) and minimum $\mathrm{SO}_{2}$ $\left(8.2 \mu \mathrm{g} / \mathrm{m}^{3}\right)$ and $\mathrm{NO}_{2}\left(19.6 \mu \mathrm{g} / \mathrm{m}^{3}\right)$ concentrations at Near Marudhamalai Temple (Up) and Car Parking Marudhamalai Temple (Up). Study carried out by Balashanmugam et al., 2012, shows that the $\mathrm{NO}_{2}$ levels have exceeded limits at all the eight sample sites and $\mathrm{SO}_{2}$ at all the eight sites has not crossed the limits. $\mathrm{NO}_{2}$ here is higher than the limit by $18 \%$, and $\mathrm{SO}_{2}$ is 57.2 percent of the limit. $\mathrm{NO}_{2}$ level is the second largest at the railway level crossing. The only source for $\mathrm{NO}_{2}$ is the auto emission, in the absence of any other industrial or commercial activities in the region.

Anyhow while comparing the earlier study (Eco friendly environmental management awareness program, 2006) suggests that the pollution levels increased two fold. Similar research was carried out at the Shiridi Sai Baba Temple in Maharashtra (Kankal and Gaikwad, 2011) were it can be seen that the concentration of SPM, $\mathrm{SO}_{2}$ and $\mathrm{NO}_{2}$ ranges from $39.93 \mu \mathrm{g} / \mathrm{m}^{3}$ to $147.56 \mu \mathrm{g} / \mathrm{m}^{3}, 19.25 \mu \mathrm{g} / \mathrm{m}^{3}$ to $38.16 \mu \mathrm{g} / \mathrm{m}^{3}$ and $6.68 \mu \mathrm{g} / \mathrm{m}^{3}$ to $9.84 \mu \mathrm{g} / \mathrm{m}^{3}$ respectively. It was observed that high $\mathrm{SO}_{2}$ concentrations were generally associated with the wind blowing from WNW-NW directions, and the high SPM concentrations were usually related to the wind blowing from $\mathrm{W}-\mathrm{NW}$ directions. The sampling was carried out for nearly nine months and SPM, $\mathrm{SO}_{2}, \quad \mathrm{NO}_{2}$ were analyzed for $8 \mathrm{hrs}$. The average concentration for SPM, $\mathrm{SO}_{2}$, and $\mathrm{NO}_{2}$ was found to be $91.61 \mu \mathrm{g} / \mathrm{m}^{3}, 27.18 \mu \mathrm{g} / \mathrm{m}^{3}, \quad 8.14 \mu \mathrm{g} / \mathrm{m}^{3}$ respectively. According to $\mathrm{CPCB}$ recommendation the pollutants concentration should be within $200 \mu \mathrm{g} / \mathrm{m}^{3}$ for SPM, 80 $\mu \mathrm{g} / \mathrm{m}^{3}$ for $\mathrm{SO}_{2}$ and $\mathrm{NO}_{2}$. 
ISSN No:-2456-2165

\begin{tabular}{|c|c|c|c|c|c|c|}
\hline \multirow{2}{*}{ Parameters } & Unit & \multicolumn{3}{|c|}{ Locations } & \multirow{2}{*}{$\begin{array}{c}\text { Standards } \\
\text { As per CPCB }\end{array}$} \\
\cline { 3 - 6 } & & 1 & 2 & 3 & 4 & \\
\hline $\begin{array}{c}\text { Particulate Matter } \\
\text { Size Less then PM10 } \mu \mathrm{g}\end{array}$ & $\mu \mathrm{g} / \mathrm{m}^{3}$ & 34.6 & 38.2 & 42.4 & 48.4 & 100 \\
\hline Sulphur Di Oxide as SO & & & & & & \\
\hline Nitrogen Di Oxide as $\mathrm{NO}_{2}$ & $\mu \mathrm{g} / \mathrm{m}^{3}$ & 8.2 & 9.6 & 13.8 & 15.6 & $\mathbf{8 0}$ \\
\hline
\end{tabular}

Table 2:- Air Quality in Different Sampling Stations in and Around Marudhamalai

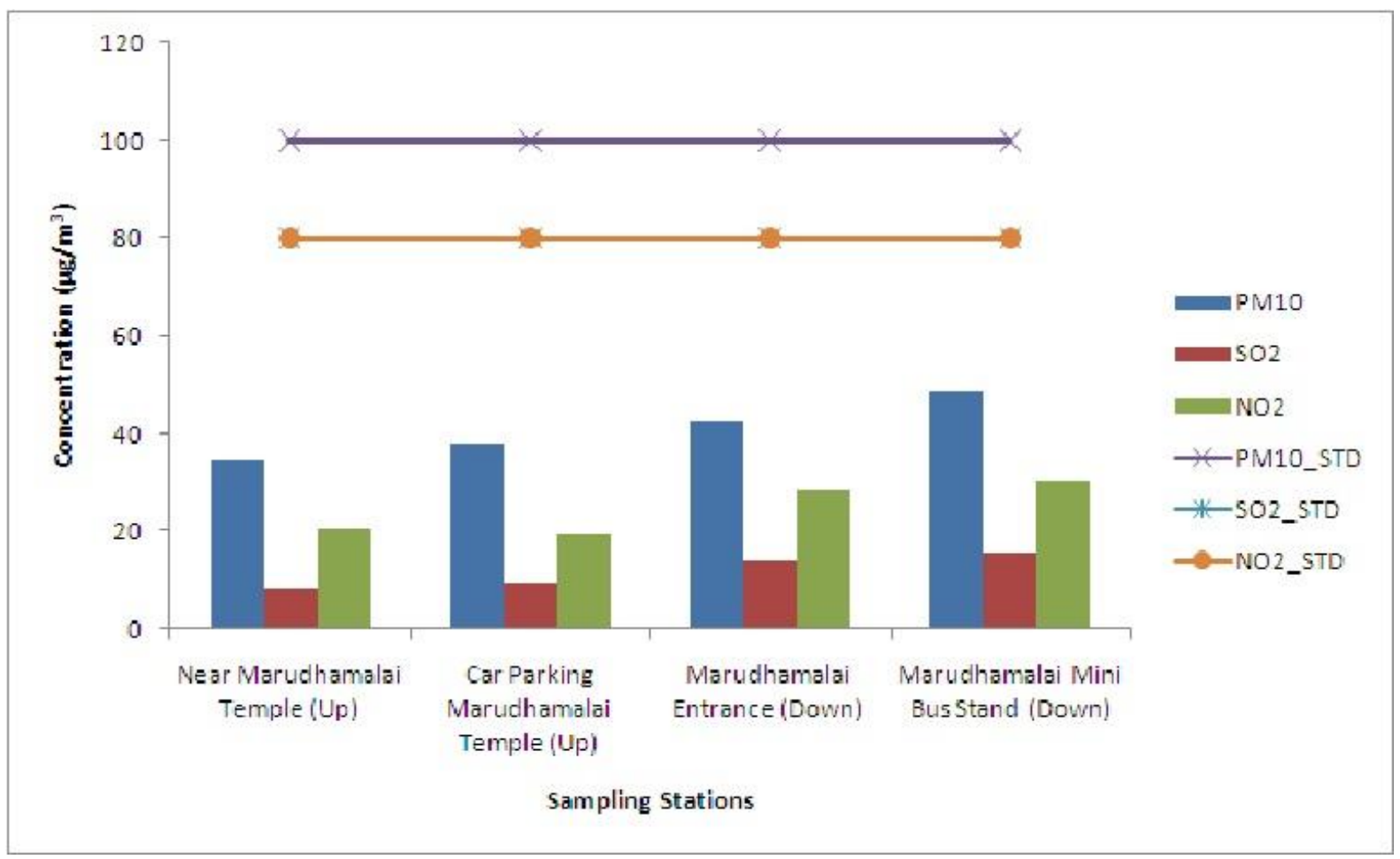

Fig 2:- Air Quality in and Around Marudhamalai

\section{SUMMARY AND CONCLUSION}

The results obtained in the study showed higher concentrations of $\mathrm{PM}_{10}, \mathrm{SO}_{2}$ and $\mathrm{NO}_{2}$ in and around the Marudhamalai Hill shrine when compared with the older records. This increment may be due to the increase in vehicular population at the temple. All three air quality parameters reveal that the maximum concentrations were obtained at the mini bus stand area were frequent movement of vehicles throng the area. But the surrounding nature maintains the concentration level below the permissible limit. Thus the study finally concludes that the air quality in and around the Marudhamalai hill shrine is perfectly below the prescribed standard limits.

\section{ACKNOWLEDGEMENT}

The authors extend their sincere thanks to the officials and management of Marudhamalai Temple trust for giving them permission to carry out the study and to the management of Greenlink Analytical and Research Laboratory for providing facilities for analysis work.

\section{REFERENCES}

[1]. Balashanmugam P., Ramanathan A. R., And Nehru Kumar V. (2012). Assessment Of Ambient Air Quality in Chidambaram a South Indian Town. Journal of Engineering Science and Technology Vol. 7, No. 3 (2012) 292 - 302.

[2]. Eco friendly environmental management awareness program - Maruthamalai temple - By Dept of Environmental Science, PSG College of Arts and Science, Coimbatore, 2006.

[3]. Kankal S. B. and Gaikwad R. W. Studies on noise and air quality monitoring at Shirdi (Maharashtra), India. Pelagia Research Library Advances in Applied Science Research, 2011, 2 (1): 63-75.

[4]. National Ambient Air Quality Standards (NAAQS), 2009. Available from http://www. cpcb.nic.in/NationalAmbient-Air-QualityStandards.php. (Accessed 20.03.2018).

[5]. Paulsamy S. (2011). Maruthamalai Hills of Western Ghats, Coimbatore District, Tamil Nadu - A potential ecosystem for medicinal plants. Journal of Research in Plant Sciences (2011) 01: 012 - 026. 
[6]. Saravanakumar R., Sivalingam S. and Elangovan S. (2016). Assessment of Air Quality Index of Coimbatore City in Tamil Nadu. Indian Journal of Science and Technology, Vol 9(41), DOI: 10.17485/ijst/2016/v9i41/99185, November 2016.

[7]. Sindhuja R., Rajendran A. and Jayanthi P. (2012) Herbaceous life forms of Maruthamalai Hills, Southern Western Ghats, India. Int. J. Med. Arom. Plants, ISSN 2249 - 4340 Vol. 2, No. 4, pp. 625 631, December 2012.

[8]. Veena Sharma and Gagan Gupta. (2017) The particulate matter concentration around the Golden Temple, Amritsar, Punjab. International Conference on Recent Innovations in Science, Agriculture, Engineering and Management, University College of Computer Applications, Guru Kashi University, Bathinda, Punjab. 20 ${ }^{\text {th }}$ November 2017. 